\title{
Impact of Community Engagement on Public Construction Projects -- Case Study of Hammanskraal Pedestrian Bridge, City of Tshwane, South Africa
}

\author{
B.D.C. Rathenam ${ }^{1, *}$, N.L. Dabup ${ }^{2}$ \\ ${ }^{1}$ Department of Building Sciences, Tshwane University of Technology, South Africa \\ ${ }^{2}$ Tsholetso Projects, Department of Project Management, Pretoria, South Africa
}

Copyright $\bigcirc 2017$ by authors, all rights reserved. Authors agree that this article remains permanently open access under the terms of the Creative Commons Attribution License 4.0 International License

\begin{abstract}
Construction projects in the public sector are often affected by major challenges with regards to project ownership by stakeholders particularly with the co-operation of local communities. Local community participation is a requirement for various development initiatives in South Africa. Various government policies and regulations exist, to support the free and fair participation of small and medium scale enterprises within the built environment, particularly with public sector projects. This research study seeks to investigate the influence of local communities on public sector construction projects and will focus on the impact of the local community involved in the construction of the Hammanskraal Pedestrian Bridge over the R101 in Hammanskraal, Pretoria. The sample population will consist of the main contractor, the professional team involved in the project and the municipality officials overseeing the project. This research will also focus on the engagement of the professional engineer and project managers with the project steering community.
\end{abstract}

Keywords Stakeholders, Stakeholder Management, Community Engagement, Project Control

\section{Introduction}

The concept of stakeholder management in project implementation particularly with regards to construction projects has advanced within the last decades, especially, with the increased move towards environmental awareness and the impact of construction projects on the environment and communities. This has brought to the fore the issue of stakeholders. Stakeholder management has become extremely relevant to project success. According to Baharuddin, Wilkinson \& Costello [1] it may be due to the fact that stakeholders in construction are directly and indirectly affected by projects. At implementation, project impacts on stakeholders optimistically and adversely due to the effects and nature of projects during its life-cycle. Baharuddin et al. [1] opine that complications such as reworks, disagreements, cost escalations, inadequate communication, and poor supply chain process are some of the challenges experienced from stakeholder conflict during the construction phase. The above problems can be attributed to the fact that different project stakeholders have differing goals and priorities, and it is, therefore, unlikely that all stakeholder expectations can be met on a project.

Researchers have advised that it is imperative for stakeholders to understand the goals and objectives of the project and be on board from the planning stage of the project. This will minimize conflict and encourage ownership (Hammad [2]; Baharuddin et al. [3]; and Molwus [4]). However, it appears that not majority of the critical stakeholders are involved right from the inception of a project. Equally, a few studies have been conducted on the implications and importance of stakeholders' involvement, in construction projects from inception.

Therefore, this paper seeks to assess the impact of the level of community engagement on public projects in Gauteng, South Africa.

\subsection{Case Study}

A study was conducted on the construction of the Hammanskraal Pedestrian Bridge. The Hammanskraal Pedestrian Bridge project entails the construction of a Pedestrian Bridge across the R101 (Route K97), linking the pedestrian walkway network between two major business nodes adjacent to the R101. The business nodes serve the entire Hammanskraal area. The project team identified the pedestrian bridge on the R101 in the Hammanskraal as a priority project for non-motorized infrastructure for the 
safety of members of the Hammanskraal community. The project is funded by the South African National Treasury under the Neighbourhood Development Partnership Grant (NDPG), in conjunction with the City of Tshwane. The project was initially slated to be completed within five months. However, due to various challenges and delays the completed date had to be extended for another seven months.

\section{Literature Review}

\subsection{Project Stakeholders}

Project stakeholders have been defined in different ways by various researchers and professional bodies. Some have argued, that some of the definitions are too constricted while some argue that the definition is too wide (Molwus [4]). Researchers have defined stakeholders as the individuals, clusters, or businesses that can affect or be affected by a resolution, task, or consequence of the project (PMBOK [5]; Malkat \& Byung-GYOO [6]; and Cooper [7]). Other researchers (Olander [8]; Aaltonen \& Kujala [9]; Chinyio \& Akintoye [10] and Winch [11]) have categorized stakeholders based on their characteristics and dispositions towards the project. Waghmare \& Bhalerao [12]; Prabhu [13] and Winch [11] in particular, classified construction project stakeholders into two categories according to their relationship with the client:

- Internal stakeholders which are those who have legal contracts binding with the client, and

- External stakeholders which are those who although have direct interest in the project but not necessarily having direct contracts with the client.

Winch [11] further broke the two groups down as internal stakeholders as those grouped around the client on the demand side and those on the supply side, while external stakeholders are subdivided into private and public actors. El-Gohary, Osman \& El-Diraby [14] define project stakeholders as clusters or entities, individuals who have stake in, or expectation of, the project's performance including clients, project managers, designers, subcontractors, suppliers, funders, users and the community at large who have power and are affected by the development directly and indirectly (Zanjirchi \& Moradi [15]). Figure 1 below shows a mapping of project's main stakeholders.

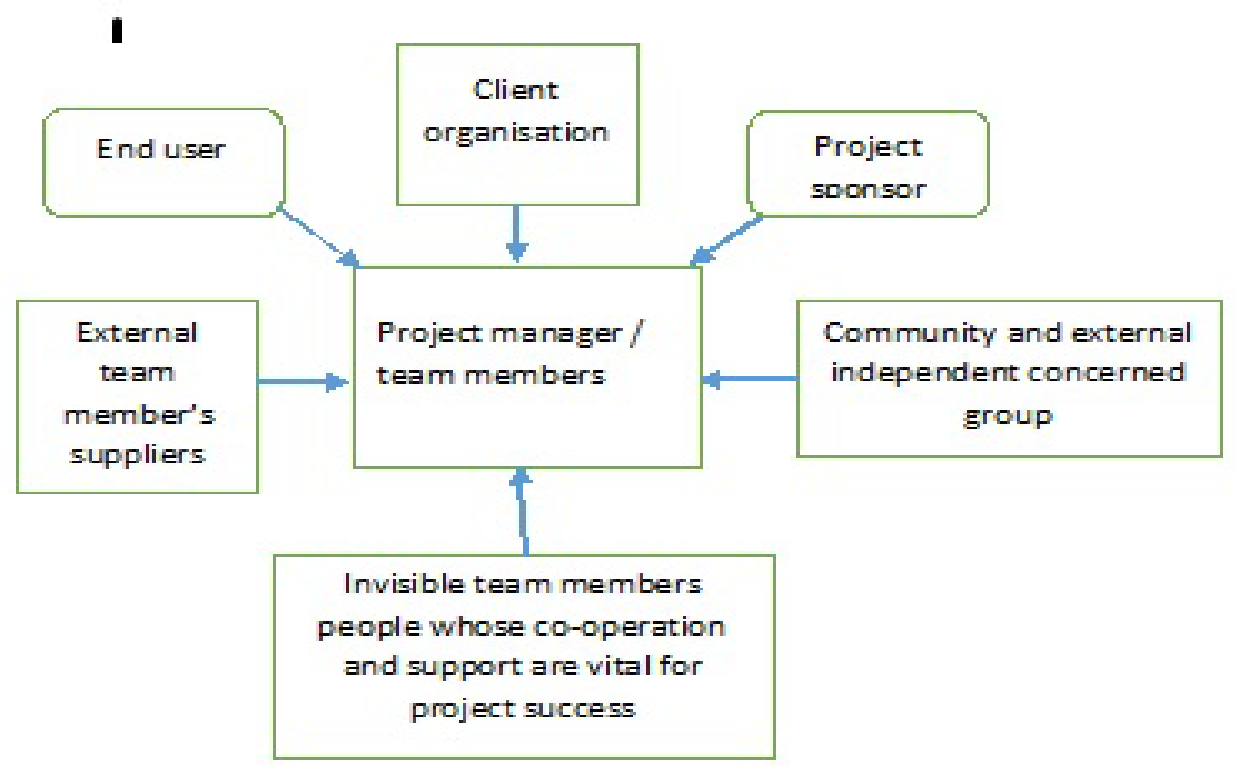

Figure 1. Walker [16] 
Despite the various definitions of stakeholders available, one common factor that researchers agree with is the level of influence they can wield on a project and the comprehension of and effective management of stakeholders' demands on the project decision making process is critical to project success Aaltonen [17].

Consequently, empirical studies have admitted to the challenges and conflicts that have risen from the project's external stakeholder environment in construction projects. The majority of the research has focused on the complex make-up of the project itself, ignoring the external stakeholder context of the projects Aaltonen [17].

\subsection{Stakeholder Management}

According to Siering \& Svensson [18] even with the unusually perplexing stakeholder milieu, stakeholder management techniques are not employed in general management operations. Instead, a mutually internal vision and mission statement serves as a behavioural standard and constituting the robust stakeholder management tool that is available. This situation is not too different from the situation in the construction industry. The importance of stakeholder management in construction projects have been emphasized and reported by a number of studies according to Yang, Shen Ho, Drew \& Chan [19]. Yang et al. [20] further posit that the construction industry has failed dismally in effectively managing stakeholders in the last decade. Although studies conducted within the industry has shown that some of the challenges of stakeholder management in construction projects include: inadequate engagement of stakeholders, project managers having unclear objectives of stakeholder management, difficulty to identify the "invisible" stakeholder, and inadequate communication with stakeholders. This assertion is in line with Molvus [4] study which investigated the current practice of stakeholder management within the construction industry. His survey results revealed that stakeholder management has yet to be fully embraced among the construction organisations. Wanga \& Jing [21] conducted a study on the relationships between key stakeholders' project performance and project success: perceptions of Chinese construction supervising engineers, their findings showed that relations among the key project stakeholders appears as the most important criterion which determines the overall success rate of a project.

In a research by Yang et al. [20] conducted on construction projects in Hong Kong, the top three critical success factors identified as effective in stakeholder management are: managing stakeholders with social responsibilities namely: economic, legal, environmental and ethical; exploring the stakeholders' needs and constraints to the project, and communicating with and engaging stakeholders properly and frequently.

Molwus [4] conducted a study on stakeholder management in the construction industry in the United
Kingdom. The results of his study indicated that; there is a strong need for internal stakeholders to collaborate in undertaking stakeholder management in construction projects. There is need to create feedback mechanisms and early warning signs to track changes in stakeholder interests / disposition throughout the project.

In trying to understand the interrelations among the critical success factors for stakeholder management in construction Molwus's [4] study further showed that stakeholder analysis cannot directly impact / influence project success. However, stakeholder engagement / empowerment being the only construct found to directly influence project success depends on the understanding of stakeholder dynamism which also depends very strongly on the results of stakeholder analysis.

A study conducted by Malkat et al. [6] relative to stakeholders of construction projects in Dubai and adjacent regions, indicated that stakeholders ranking based on their highest influence on project spheres, showed that project managers are the highest ranked and the community is the lowest ranked. This study corresponds to Prabhu's [13] study on the influence of stakeholders in the construction industry with a focus on Northern India which showed the project management consultant as the key stakeholder on projects within that region.

In investigating salient stakeholder attributes and assigning only one attributes, power, legitimacy, and urgency to each stakeholder, the results gave an idea on the most significant stakeholders that counts in terms of attribute. The stakeholders include the client, sub-contractors, suppliers, financial firms, and community. Clients are core stakeholders at $67.5 \%$, respondents feel the need to adhere to client's wish and keep him satisfied. In addition, $81.8 \%$ of respondents believed that clients possess the power attribute. For legitimacy and urgency, third parties, communities and sub-contractors accounted for $55.8 \%$ respectively Malkat $e t$ al. [6].

Initiating the engagement process in a project's early phase ensures timely public access to all relevant information and gives the stakeholders an opportunity to provide input into the project design and the assessment of impacts (Baharuddin et al. [3]). Hammad [2] agrees with this and suggests that in today's project environment, stakeholders are an integral aspect of the successful delivery of projects as ever so often projects are motivated by the actions and decisions of relevant stakeholders.

Prabhu [13] asserts that the following constitute the key principles of stakeholder management:

- Early and frequent consultations with stakeholders;

- Engage with stakeholders respectively and sensitively;

- Pay attention / heed and be attentive to stakeholders needs and requirements;

- Adequate and timely planning of stakeholder management is critical;

- Engender an atmosphere of trust and credibility within the project environment; 
- Communication and feedback such that all messages is understood by the intended audience and hence the feedback will be articulate;

- Manage stakeholders as risk and opportunities which have probabilities and impacts;

- Compromise through the set of stakeholders differing requirements and needs;

- Conduct extensive inquiry to understand the significance of the project to the stakeholder, and

- Taking accountability of the entire project and processproject governance is critical to project success.

\subsection{Stakeholder Engagement}

El-Gohary et al. [14] and Olander [8] conducted research on project stakeholder's issues, and alluded to the fact that the activities and practices undertaken by key parties have irrefutable bearings on project results. Thus, identification of the vital roles of strategic members on projects has therefore developed more in recent years. However, Terry, Thomas \& Skitmore [22] and Zou [23] report that it is no longer enough to inform and identify project stakeholders but it has become imperative to effectively manage project stakeholders in order to ensure project success. Hence, project managers must appreciate that stakeholder's expectations are as disparate as the various stakeholders on a project and it is imperative for project managers to develop strategies to manage those expectations (Aaltonen [17]).

Therefore, a significant part of the stakeholder engagement process should be to precisely evaluate the importance and influence levels of these groups and their potential orientation towards the project (Waghmare \& Bhalerao [12] and Olander [8]).

Ekung et al. [24] posit that to reduce conflicts and encourage support between the firms and stakeholders, project managers must ensure they execute a strategic stakeholder's engagement process. It may not be possible to totally avoid disagreement between the stakeholder management \& engagement. Ekung et al. [24] citing Kivits [25] alludes that the stakeholder's salience defines the engagement approaches to be adopted. Engagement is a well-thought-out process incorporating arrangements to negotiate, establishing negotiation standards and reviewing the aftermath (Ekung et al. [24]).

To further enhance effective engagement, Ekung et al. [24] suggested that it is imperative to form project alliance with the stakeholders as significant measures in the stakeholder needs pyramid. Key factors during stakeholder engagement process must include trust, teamwork, understanding, and respect (Buckley [26]). This ensures that stakeholder engagement is tailored towards interest resolution on a mutual rostrum. Jing \& Jian [27] conducted a study to examine every aspect in Chinese project delivery system, and discovered that one of the most important success criteria for Chinese project practitioners was creating and sustaining respectable personal relationship among various stakeholders. They concluded that informal relationships among project stakeholders in Chinese projects play a critical role in project success relative to stakeholder engagement Ekung et al. [24] suggests that there are three basic levels of engagement:

- Firstly, providing vertical information which is ardently aimed at ensuring that stakeholders are kept up-to-date: - Secondly, when the construction organisation establishes a two-way two path interaction which ranges from sheer information release to listening and obtaining feedback.

- Thirdly, active participation- a relationship based on alliance with the stakeholders which embraces information disclosure and keenly working with stakeholders.

Public hearings and design charrettes are considered the most important stakeholder engagement instruments according to (Molwus [4]).

\subsection{The Concept of Stakeholder Satisfaction}

Terry, Thomas \& Skitmore [22] posits that in contemporary times the notion of customer satisfaction has emerged, mainly in the manufacturing sector and end-user services markets, as being "a comparison between the end-user's pre-purchase expectations and their post-purchase perceptions".

However, within the built environment industry, the idea of construction stakeholder satisfaction is only just becoming significant mainly because stakeholders are beginning to impact on project outcome based on their individual interests and requirements (Terry et al. [22]).

Olaku, Ibrahim, Abdulmumin, Adeniran, \& John [28] opine that stakeholders' perceptions of project success are very important. It is imperative for stakeholders to be satisfied, to ensure the project is classified as successful by the stakeholder group. This implies that the construction industry is now accepting the idea that stakeholder satisfaction, cost, time and quality are factors which determine project success (Yang, Huang, \& Wu [29]). As oppose to the traditional criteria for measuring the success of construction projects which use to be based on quality, time and cost (Windapo \& Qamata [30]; Zungu \& Fore [31]; Zanjirchi \& Moradi [15] and Nguyen, Skitmore, \& Wong [32]).

However, Zanjirchi \& Moradi [15] further posited that project success is also measured using numerous other factors, some of which include: organisational objectives; stakeholders' satisfaction; end-user benefit, future potential to organisation, etc.

The soaring rise of failed projects is due to the neglect of stakeholders, and an unsatisfied stakeholder or stakeholder group will result in the conclusion that the project is unsuccessful. Hence, project managers must prioritize stakeholder management in the project management process (Olaku et al. [28] and Nguyen et al. [32]).

Olaku et al. [28] suggested that the stakeholder 
management process commences with identifying the project stakeholders, determining what they want and predicting what they will do, based on their perception of the project. The major aspect of this process based upon the project managers, appreciation of the stakeholder's perception of the project success as it relates to the stakeholders group (Zanjirchi et al. [15]).

According to Waghmare \& Bhalerao [12] stakeholder satisfaction should be managed as a key project objective.

\subsection{Communities}

Mnaranara [33] citing the research works of Dalby \& Mackenzie [34] defines communities based on specific geographical site. Mnaranara [33] further cites Fortman \& Roe's [35] definition of communities which is based on characteristics which residents share, some of which include culture, language, tradition, law, geography, class and race. This implies that a community is a cluster of people with a shared identity cohabiting together within a particular location.

The idea of community is an unclear concept. It captures subjects of uniqueness and belonging, connection and variance, inclusion and segregation, habitation and time, processes such as modernisation, and has been considered both a spatial and social phenomenon (Clark [36]).

Mnaranara [33] alludes that communities are governed and managed by either democratically elected leaders who act relatively autonomously from other levels of government, or are governed by leaders imposed from top authorities and represent central authorities.

Finally, Mnaranara [33] citing Zenter [37] highlights three features of communities.

- A community is a group structure, whether legally or illegally organised; in which participants play roles which are unified around objectives related to the challenges resulting from shared occupation and utilization of occupied space:

- Members of the community have some level of communal identification with the occupied space.

- A community has an amount of indigenous sovereignty

Relative to this study, a local community is defined as an area created "for the exclusive ownership and occupation of a designated group" as described in the South African, Group Areas Act of 1950 [38] where an entire population was to be segregated and allocated separate residential areas.

\subsection{Community Stakeholders}

In a research study conducted by Maddaloni [39] on rethinking the role of community stakeholders in megaprojects, he discovered that stakeholder management research has focused intensely on primary stakeholders' who are able to control project resources, whilst the effect of megaprojects on the authentic secondary stakeholders remains broadly uncharted.
Maddaloni [39] further posits that the impact of megaprojects on people and location at the local community level is relatively under researched as oppose to research conducted to understand how secondary stakeholders can influence projects.

Therefore, the constituency of the local community offers an interesting perspective to research because it's repeatedly excluded from the project communication plan, which has resulted in negative implications for project success.

According to Ekung et al. [24] community stakeholders are made up of three distinct groups:

- Social group- these are individual household groups which form the core of unskilled labour within the production environment;

- Economic group- are kingmakers within the community with suitable power to rally resources or detain movement of resources into project organisation, and

- Political groups- are the established agency of government in the community-local councillor's chambers, youth organisations. Based on their distinctiveness and degree of resistance they pose to projects; effective engagement is therefore a critical step to ensuring successful project outcomes.

The South African government has integrated policies which ensure community participations on construction projects in the country. Some of these policies include the Expanded public works programme (EPWP) which encourages public sector projects to be constructed using labour intensive methods, and a political promise that $25 \%$ of any project executed within a community must be unpacked for community SMME's (Alli \& Emery [40]).

However, according to Alli \& Emery [40] it is often difficult for a professional to engage in grassroots participation unless there are in the short term political negotiations which will involve local negotiations with structures over issues of control.

Nonetheless, community involvement is a very important aspect of project success particularly with development projects, irrespective of the size. Community ownership of a project is key to project take-off and project acceptance.

\subsection{Community Participation}

Khan [41] citing Chambers [42] suggest that the new acceptance of participation has quite a few origins:

- Acknowledging that many developments fail due to attempts to enforce typical top down programmes and projects on diverse local realities where they do not fit or meet needs;

- Apprehension over profitability, identifying that the more local people do, the less capital costs are likely to be;

- Fixation with sustainability, and the operating budget that if local people themselves design and construct 
they are more likely to meet operating budget and undertake maintenance; and

- The belief that it is poor people that should be empowered and should have more command over their lives.

Thwala [43] posits that the aim of community engagement on a project is for the purpose of equipping communities; developing competency, ensuring project success, ensuring user satisfaction, and project cost sharing. Thwala [43] further alludes that communities are highly complex and since they are not single cohesive units, it is imperative that in the absence of a legal and active local authority, other representatives of the community have to be identified and made a part of the consultation process.

Rosario \& Goh [44] listed the key principles of community consultation and community stakeholder engagement as:

- Community engagement - this means that project managers must develop a translucent community engagement strategy which all stakeholders must be aware of at project initiation phase. Identify the significance of community participation / involvement and gathering local knowledge during project conception phase. Plan and design deliberation / negotiation process with stakeholders from within the community where the project will be executed. The application of a comprehensive tactic to scrutinise all relevant stakeholder groups, the use of interactive techniques appropriate to the local context and ensuring a tripartite flow of communication, which will be downhill, parallel, and uphill. All of these require a lucid and easily accessible at any time and in all engagement activities.

Siering \& Svensson [18] posit that engaging external stakeholders with a significant amount of grit and stoicism increases the prospect of achieving the coveted results. Compelling and deliberate communication is critical to managing associations productively. It is therefore, imperative to be able to predict and recognize all relevant stakeholders and, most essentially, be sensitive to their needs and requirements thereby pre-emptively thwarting a deleterious resistant towards the project (Kambuga [45]). Kambuga [45] advised on the following:

- Circulating information \& garnering feedback. analyse matters of opinion, interactive consultation with stakeholders, explaining how their views have been addressed / incorporated into the plan, the plan must be kept open ended. Engagement with the community must be kept ongoing. Project design or proposal must be communicated and talked over timeously. It is important to recognise opposition's influence, to set expectations, assuage plans and establish consultation strategies. Finally, it is vital to be aware of the significance of communal and informal networks
Collective association with communities-employ local resources where available for jobs such as sub-contracting and general labour. Talk over alleviation and beneficial measures with local community. Development should be appropriate and beneficial to the local community, in line with good corporate citizenship and Corporate Social Responsibility (CSR).

Finsterbusch \& Van Wicklin [46] stated that at times, engaging with local communities brings about political opposition particularly in countries where most beneficiaries are excluded from the political system. Situations like that tends to be perceived as imperil to political leaders, or as otherwise disturbing the political stability and engendering demands and pressures that governments cannot or do not want to respond to.

On the other hand, Nalewaik \& Anthony [47] posit that failure of the project manager to provide continuous information and feedback on the project and progress to the end-users during the design and implementation phases of the project, collaboration between the stakeholder groups throughout all project phases may have considerable negative impact on perceptions of project success - not just cost and schedule, but customer satisfaction and the very usability of the infrastructure. They further provide a list of factors which can influence project performance negatively if not properly managed to include:

- Conflicting priorities between stakeholders; differing levels of urgency by stakeholders;

- The politics and stakeholder relationships intrinsic in public sector projects, and

- Difficulty in satisfying a diverse and ever-changing stakeholder population, and management of change.

Nalewaik \& Antony [47] state that communication is vital to stakeholder engagement, and must be on a continuous basis. They posit that project managers should consider preparing reports based on engagement with and understanding of stakeholders, this will ensure that the generated reports are understood by and relevant to the intended audience. They advise that project status report should be tailored to specific stakeholder group. Hence project managers may need to consider generating different multiple reports as oppose to a one-size-fit all report.

Buckley [26] affirms that during a project construction phase, it is critical that community engagement is conducted in such a manner that it involves collaborating with the community by keeping communities informed, and devote in listening to and recognizing anxieties, and provide feedback on how the community's contributions influence decisions.

Buckley [26] further posits that project and construction team members need to make certain that they are conscious of, and dedicated to, the project's communication plan and strategy for communicating with local stakeholders. Seemingly, contractors are usually under time and cost pressure to deliver certain works and can overlook the 
project's communication requirements and, indeed, the consequences of not informing relevant residents, companies or other stakeholders. To ensure that the appropriate information is provided early to relevant stakeholders. Buckley [26] advises that it should be passed across at site inductions, and it should include a briefing on communication and community engagement / participation, and it should be passed across to site teams and subcontractors every day at site works commencement meetings or even as part of regular site toolbox talks.

According to Buckley [26] communication, staff needs to emphasize on the importance of notification timeframes at project team meetings and during deliberations about prospective works. However, even when precautionary measures are adopted to responsively manage concerns and grievances, unfortunately, the reality is that interferences and conflicts are inevitable with most infrastructure projects, and objections are certain (Buckley [26]).

However, the main obstacle to engaging with stakeholders in general and local communities particularly is the difficulty of implementing it in practice. Extra time and resources are required to rally less developed communities. The consultation process becomes time consuming due to the multitude of people that need to be consulted as oppose to a situation where the project can be executed without local community involvement. Furthermore, there is a tendency for projects that require community engagement to lose momentum and drag on for a longer period than necessary (Finsterbusch et al. [46]).

This they say is likely to result in delicate projects becoming overstrained and hence after collapsing due to organisational complexity or the frustration of those involved.

\section{Research Methodology}

The current study entailed a review of literature relevant to stakeholder management with emphasis on stakeholder engagement and local community. The search included investigations of journal publications and materials from the academic community.

A case study on the Hammanskraal bridge project was conducted. To aid the empirical study, a questionnaire was designed, based on a review of the available literature pertaining to stakeholder management in construction projects.

The questionnaire was devised to understand which stakeholders had the most influence and impact on project delivery process and the stakeholder factors which caused delays on the Hammanskraal bridge project. The questionnaire was framed and aligned to the major challenges experienced on the Hammanskraal bridge project, to assist in understanding the causes of conflict and frictions on the project. The project was selected for this study because it was a community based project and had multiple stakeholders.

Respondents to the questionnaire included members of the professional team, client and the contractor. The study was limited to this group of people as they were at the fore of the project delivery process and were affected by the various challenges experienced on the project from various stakeholders.

\section{Research Findings}

The Relative Importance Index (RII) system was used to rank the respondents' perceptions in order to determine which factors were ranked higher than others and hence considered more important. The output from the analysis was presented in graphs, charts and tables.

Twelve (12) individuals, who work as professionals within the construction industry and were directly involved in the construction of the Hammanskraal pedestrian bridge project, were contacted via email and requested to participate in the completion of the survey. From the selected twelve (12) individuals, nine (9) respondents completed and returned the questionnaires.

The respondent population is made up of professionals within the built environment industry with varying years of experiences in the industry. The first part of the questionnaire covers the demographics information of the respondents indicating their experience, job title, organisation, and the number of years their organisation have been operating within the industry.

From the respondents a total of seven are graduates, one has a postgraduate degree and one holds a doctorate degree. Although all the respondents work in the built environment, four of them have experience of between 5-10 years, two have experience of 15-20 years and three have experiences of more than 20 years. The respondents range from top, middle to junior management levels. Even though the project was funded by the public sector, only two of the respondents work in the public sector, while seven of the respondents work within the private

The first objective was to assess the extent to which stakeholders influence the Hammanskraal pedestrian bridge project. The research undertaken established that stakeholders had a high impact project with an aggregated relative importance index of 0.656 . From the summary of results in Table 1, it can be observed that the stakeholders ranked most influential on the project were the community $(\mathrm{RII}=0.796)$, the Project Manager $(\mathrm{RII}=0.778)$, the structural Engineer $(\mathrm{RII}=0.741)$ and the Hawker Committee $(\mathrm{RII}=0.704)$. It is notable that the result of the survey indicates that the community was more influential on the project than any member of the professional team which is contrary to the literature study which indicated that the project manager is the most influential stakeholder. 
Table 1. The extent to which the stakeholders influence the Hammanskraal Pedestrian Bridge project

\begin{tabular}{|c|c|c|c|c|c|c|c|c|}
\hline \multirow{2}{*}{ Stakeholders } & \multirow{2}{*}{ Unsure } & \multicolumn{5}{|c|}{ Low..........................High } & \multirow{2}{*}{ RII } & \multirow{2}{*}{ Ranked } \\
\hline & & 1 & 2 & 3 & 4 & 5 & & \\
\hline Community & 0 & 0 & 0 & 0 & 2 & 7 & 0.796 & 1 \\
\hline Project Manager & 0 & 0 & 0 & 0 & 3 & 6 & 0.778 & 2 \\
\hline Structural Engineer & 0 & 0 & 0 & 1 & 3 & 5 & 0.741 & 3 \\
\hline Hawker Committee & 0 & 0 & 0 & 2 & 3 & 4 & 0.704 & 4 \\
\hline Contractor & 0 & 0 & 0 & 3 & 1 & 5 & 0.704 & 5 \\
\hline Project Steering Committee & 1 & 0 & 0 & 3 & 3 & 3 & 0.667 & 6 \\
\hline Community Liaison Officer & 0 & 0 & 1 & 1 & 5 & 2 & 0.648 & 7 \\
\hline $\begin{array}{l}\text { Gauteng transport and public } \\
\text { works department- Gautrans }\end{array}$ & 0 & 0 & 1 & 3 & 2 & 3 & 0.630 & 8 \\
\hline City of Tshwane & 0 & 0 & 2 & 1 & 3 & 3 & 0.630 & 9 \\
\hline Client & 0 & 1 & 1 & 1 & 4 & 2 & 0.593 & 10 \\
\hline Material Suppliers & 0 & 0 & 2 & 1 & 6 & 0 & 0.574 & 11 \\
\hline Local labour & 0 & 0 & 2 & 4 & 2 & 1 & 0.537 & 12 \\
\hline Subcontractors & 0 & 0 & 2 & 5 & 1 & 1 & 0.519 & 13 \\
\hline
\end{tabular}

The second objective of the survey was to establish the nature of stakeholders' influence on the project. Table 2 indicates the nature of stakeholder influence on the Hammanskraal Pedestrian Bridge project in terms of percentage responses to a scale of 1 (positive) to 5 (negative). The respondents attributed the top five stakeholders to have negatively influenced the project as Hawker Committee $(\mathrm{RII}=0.685)$, the community $(\mathrm{RII}=0.611)$, the community liaison officer $(\mathrm{RII}=0.537)$, the project steering committee $(\mathrm{RII}=0.444)$ and the local labour $(\mathrm{RII}=0.444)$. It is notable that in general the respondents can be deemed to perceive the local community and local committees to have a negative influence on the Hammanskraal Pedestrian Bridge Project.

Table 2. The nature of stakeholder influence on the Hammanskraal Pedestrian Bridge project

\begin{tabular}{|c|c|c|c|c|c|c|c|c|}
\hline \multirow{2}{*}{ Stakeholders } & \multirow{2}{*}{ Unsure } & \multicolumn{5}{|c|}{ Positive................Negative } & \multirow{2}{*}{ RII } & \multirow{2}{*}{ Ranked } \\
\hline & & 1 & 2 & 3 & 4 & 5 & & \\
\hline Hawker Committee & 0 & 0 & 2 & 0 & 2 & 5 & 0.685 & 1 \\
\hline Community & 0 & 1 & 2 & 0 & 2 & 4 & 0.611 & 2 \\
\hline Community Liaison Officer & 0 & 0 & 3 & 3 & 1 & 2 & 0.537 & 3 \\
\hline Project Steering Committee & 1 & 1 & 2 & 2 & 2 & 1 & 0.444 & 4 \\
\hline Local labour & 0 & 1 & 3 & 3 & 2 & 0 & 0.444 & 5 \\
\hline Government Agency: Gautrans & 0 & 3 & 1 & 4 & 1 & 0 & 0.389 & 6 \\
\hline Subcontractors & 0 & 1 & 5 & 3 & 0 & 0 & 0.370 & 7 \\
\hline City of Tshwane & 0 & 2 & 4 & 3 & 0 & 0 & 0.352 & 8 \\
\hline Material Suppliers & 0 & 2 & 6 & 0 & 1 & 0 & 0.333 & 9 \\
\hline Structural Engineer & 0 & 7 & 1 & 1 & 0 & 0 & 0.222 & 11 \\
\hline Client & 0 & 7 & 1 & 1 & 0 & 0 & 0.222 & 12 \\
\hline Project Manager & 0 & 7 & 2 & 0 & 0 & 0 & 0.204 & 13 \\
\hline
\end{tabular}

The survey also sought to determine the factors that influenced the delay on the Hammanskraal pedestrian bridge project as a third objective in table 3 . The survey undertaken established that community factors emerged as the highest factors influencing delays overall in the project, all of which exceed the aggregated relative importance index of 0.433 . The respondents attributed the top five factors influencing delay as Socio-political factors in the form of strikes, civil unrest by the community $(\mathrm{RII}=0.759)$, Local traders' union interference $(\mathrm{RII}=0.667)$, Lack of support from the local ward councilor (RII $=0.611)$, Bad public relations practices in dealing with communities $(\mathrm{RII}=0.611)$ and Conflict with local labour on site $(\mathrm{RII}$ $=0.574)$. 
Table 3. Factors that influenced delays on the Hammanskraal Pedestrian bridge project

\begin{tabular}{|c|c|c|c|c|c|c|c|c|}
\hline \multirow{2}{*}{ Statements } & \multirow{2}{*}{ Unsure } & \multicolumn{5}{|c|}{ Minor.............................jor } & \multirow{2}{*}{ RII } & \multirow{2}{*}{ Ranked } \\
\hline & & 1 & 2 & 3 & 4 & 5 & & \\
\hline $\begin{array}{l}\text { Socio-political factors in the form of } \\
\text { strikes, civil unrest by the community }\end{array}$ & 0 & 0 & 0 & 1 & 2 & 6 & 0.759 & 1 \\
\hline Local traders' union Interference & 0 & 1 & 1 & 0 & 2 & 5 & 0.667 & 2 \\
\hline $\begin{array}{l}\text { Lack of support from the local ward } \\
\text { councilor }\end{array}$ & 0 & 0 & 1 & 4 & 1 & 3 & 0.611 & 3 \\
\hline $\begin{array}{l}\text { Bad public relation practices in dealing } \\
\text { with communities }\end{array}$ & 0 & 0 & 0 & 4 & 4 & 1 & 0.611 & 4 \\
\hline Conflict with local labour on site & 0 & 0 & 3 & 1 & 3 & 2 & 0.574 & 5 \\
\hline $\begin{array}{l}\text { Lack of support from the community } \\
\text { liaison officer }\end{array}$ & 0 & 0 & 3 & 2 & 1 & 3 & 0.574 & 6 \\
\hline $\begin{array}{l}\text { Local plant \& equipment hire rates } \\
\text { market related }\end{array}$ & 0 & 1 & 1 & 2 & 5 & 0 & 0.537 & 7 \\
\hline $\begin{array}{c}\text { Delayed approvals from government } \\
\text { agencies }\end{array}$ & 0 & 3 & 0 & 1 & 3 & 2 & 0.519 & 8 \\
\hline $\begin{array}{c}\text { Lack of support from government } \\
\text { agencies }\end{array}$ & 0 & 2 & 1 & 4 & 0 & 2 & 0.481 & 9 \\
\hline Unavailability of plants and equipment & 0 & 2 & 2 & 1 & 3 & 1 & 0.481 & 10 \\
\hline $\begin{array}{l}\text { Disruption of site works due to health } \\
\text { and safety concerns }\end{array}$ & 0 & 1 & 3 & 4 & 1 & 0 & 0.426 & 11 \\
\hline $\begin{array}{c}\text { Late production of revised drawings by } \\
\text { engineer }\end{array}$ & 0 & 2 & 4 & 2 & 0 & 1 & 0.389 & 12 \\
\hline $\begin{array}{l}\text { Disruption of site works due to } \\
\text { environmental concerns }\end{array}$ & 0 & 2 & 3 & 3 & 1 & 0 & 0.389 & 13 \\
\hline $\begin{array}{l}\text { Insufficient skills from the construction } \\
\text { team }\end{array}$ & 1 & 2 & 2 & 2 & 2 & 0 & 0.370 & 14 \\
\hline $\begin{array}{c}\text { Mistakes and discrepancies in design } \\
\text { documents }\end{array}$ & 0 & 3 & 2 & 4 & 0 & 0 & 0.352 & 15 \\
\hline $\begin{array}{l}\text { Late payment of labour's wages by } \\
\text { contractor }\end{array}$ & 0 & 1 & 6 & 2 & 0 & 0 & 0.352 & 16 \\
\hline $\begin{array}{l}\text { Lack of clients understanding of the } \\
\text { design, procurement, and construction } \\
\text { processes }\end{array}$ & 0 & 3 & 2 & 4 & 0 & 0 & 0.352 & 17 \\
\hline Inadequate design by the engineer & 0 & 3 & 4 & 0 & 2 & 0 & 0.352 & 18 \\
\hline Late delivery of material to site & 0 & 3 & 3 & 3 & 0 & 0 & 0.333 & 19 \\
\hline Incorrect material delivered to site & 0 & 3 & 4 & 2 & 0 & 0 & 0.351 & 20 \\
\hline Lack of support from client & 0 & 3 & 5 & 0 & 1 & 0 & 0.315 & 21 \\
\hline $\begin{array}{c}\text { Change in material types and } \\
\text { specifications during construction }\end{array}$ & 1 & 3 & 2 & 3 & 0 & 0 & 0.296 & 22 \\
\hline $\begin{array}{l}\text { Inadequate communication between the } \\
\text { construction team and the project team }\end{array}$ & 0 & 5 & 2 & 2 & 0 & 0 & 0.278 & 23 \\
\hline Inappropriate business practices & 1 & 2 & 6 & 0 & 0 & 0 & 0.259 & 24 \\
\hline Late payment by client & 0 & 7 & 2 & 0 & 0 & 0 & 0.204 & 25 \\
\hline
\end{tabular}

\section{Discussion and Conclusions}

The literature study showed that stakeholder management is a vital aspect in ensuring the success of a construction project. It also showed that that although the local community is considered a stakeholder minimal consideration and engagement is given to the local community as a stakeholder.

The study conducted by Malkat et al. [6] relative to stakeholders of construction projects in Dubai and adjacent regions, indicated that stakeholders ranking based on their highest influence on project spheres, showed that project managers are the highest ranked and the community is the lowest ranked. However, through this survey study it has been determined that among all the stakeholders on projects in the public sector, in particular the Hammanskraal Pedestrian Bridge Project, the local community proved to be a major factor on the project influencing both time and cost.

This could be attributed to the fact that South Africa is a third world country in the process of development, which could be a subsequent research topic.

Understanding and exploring the influence of community engagement on public projects would allow a possibility of improving time and cost measures within construction projects. 


\section{REFERENCES}

[1] Baharuddin, H. E. A., Wilkinson, S., and Costello, S. B. (2013). Evaluating Early Stakeholder Engagement (ESE) as a Process for Innovation. Paper presented at the CIB World Building Congress, Brisbane, Australia, 2013.

[2] Hammad, S. (2013). Investigating the stakeholder management in construction projects in the Gaza Strip. An MSc Thesis. The Islamic University, Gaza.

[3] Baharuddin, H.E.A., Wilkinson, S. and Costello, S. (2014). Enhancing features of early stakeholder engagement in expressway projects. Proceedings of the 4th New Zealand Built Environment Research Symposium (NZBERS). Auckland, New Zealand. 14 November. ISSN 2324-1829 (Online).

[4] Molwus, J. J. (2013). Stakeholder management in construction projects: a life cycle based framework A PhD Thesis. Heriot Watt University, Edinburgh.

[5] Project Management Institute. (2013). A Guide to the Project Management Body of Knowledge (PMBOK) Guide 5th Edition. ISBN: 13 9781935589679, Pennsylvania.

[6] Malkat, M. and Byung-GYOO, K. (2012). An Investigation on the Stakeholders of Construction Projects in Dubai and Adjacent Regions. International Proceedings of Economics Development \& Research, 45:13, pp. 77-82.

[7] Cooper, K. R. (2014). Exploring stakeholder participation in non-profit collaboration. Submitted in partial fulfilment of the requirements for the degree of Doctor of Philosophy in Communication in the Graduate College of the University of Illinois at Urbana-Champaign, 2014.

[8] Olander, S. (2007). Stakeholder impact analysis in construction project management, Construction Management and Economics, 25: 3, pp 277-287.

[9] Aaltonen, K. and Kujala, J. (2010). A project lifecycle perspective on stakeholder influence strategies in global projects. Scandinavian Journal of Management, 26:4, pp 381-397.

[10] Chinyio, E. A. and Akintoye, A. (2008). Practical approaches for engaging stakeholders: findings from the UK, Construction Management and Economics, 26: 6, pp 591-599.

[11] Winch, G. M. (2010). Managing Construction projects: an information processing approach, 2nd Edition, Wiley-Blackwell, West Sussex, UK.

[12] Waghmare, Y. M. and Bhalerao, N. (2016). An overview of stakeholder management in construction industry. International journal of Science Technology and Management, 5:7, pp 135-142.

[13] Prabhu, P.G. (2016). Study on the influence of stakeholders in construction industry. International Journal of Engineering Technology, Management and Applied Sciences, 4:6, pp 31-45.

[14] El-Gohary, N.M., Osman, H. and El-Diraby, T.E. (2006). Stakeholder management for public private partnership. International Journal of Project Management, 24:2006, pp 595-604.
[15] Zanjirchi, S.M. and Moradi, M. (2012). Construction project success analysis from stakeholders' theory perspective. African Journal of Business Management, 6:15, pp 5218-5225.

[16] Walker, D.H.T. (2003). Procurement Strategies: A Relationship-based Approach. Blackwell Publishing, Oxford.

[17] Aaltonen, K. (2010). Stakeholder management in international projects. A PhD thesis. Aalto University School of Science and Technology, Department of Industrial Engineering and Management doctoral dissertation series.

[18] Siering, J. and Svensson, A. (2012). Managing external stakeholder relationships in PPP projects: a multidimensional approach. An MSc thesis. Chalmers University of Technology Gothenburg, Sweden.

[19] Yang, J., Shen, G.Q., Ho, M., Drew, D.S. and Chan, A.P.C. (2009). Exploring critical success factors for stakeholder management in construction projects. Journal of civil engineering and management, 15:4, pp 337-348.

[20] Yang, J.R., Shen, P.Q.G., Bourne, L., Ho, C.M.F. and Xue, X. (2011). A typology of operational approaches for stakeholder analysis and engagement: findings from Hong Kong and Australia. Construction Management and Economics, 29:2, pp $145-162$.

[21] Wanga, X. and Jing, H. (2005). The relationships between key stakeholders' project performance and project success: Perceptions of Chinese construction supervising engineers. International Journal of Project Management, 24:3, pp 253-260.

[22] Terry, H.Y., Li, S., Thomas Ng and Skitmore, M. (2013). Evaluating stakeholder satisfaction during public participation in major infrastructure and construction projects: A fuzzy approach. Automation in Construction, 29:2013, pp 123-135.

[23] Zou, W. (2012). Relationship management in public private partnership infrastructure projects. $\mathrm{A} \mathrm{PhD}$ thesis. The University of Hong Kong, Hong Kong.

[24] Ekung, S.B., Okonkwo, E. and Odesola, I. (2014). Factors influencing construction stakeholders' engagement outcome in Nigeria. International Letters of Natural Sciences, 15:2, pp 101-114.

[25] Kivits, R.A. (2013). Multi-dimensional Stakeholder Analysis: A Methodology Applied to Australian Capital city Airports'. A PhD thesis. Southern Cross University, Lismore, NSW.

[26] Buckley, A. (2012). Best practice community engagement for infrastructure projects: Building community ties that dig deeper. Public Infrastructure Bulletin, 1:8, pp 1-2. Available at: http://epublications.bond.edu.au/pib/voll/iss8/3

[27] Jing, L. and Jian, Y. (2014). An Empirical Study of the Importance and Uniqueness of Stakeholder Management in China. Journal of Business and Management, 2, pp 298-304.

[28] Olaku, A.P., Ibrahim, S., Abdulmumin, A., Adeniran, O.W. and John, T.A. (2015). Evaluation of perception of stakeholders on key performance indicators for U.B.E building projects. Journal of Multidisciplinary Engineering Science and Technology (JMEST), 2:3, pp 277-285. 
[29] Yang, L.R., Huang, C.F. and Wu, K.S. (2011). The association among project manager's leadership style, teamwork and project success. International Journal of Project Management, 29:3, pp 258-267.

[30] Windapo, A. and Qamata, G. (2015). Evaluation of the Satisfaction Metrics used by Stakeholders on Large Engineering Projects. Journal of Engineering, Project, and Production Management, 5:2, pp 82-90.

[31] Zungu, M. and Fore, S. (2014). The impact of stakeholder communication on quality of facilities management projects International conference on emerging trends in computer and image processing (ICETCIP'2014) Dec. 15-16, 2014, PattayaThailand.

[32] Nguyen, N. H., Skitmore, M. and Wong, J.K.W. (2009). Stakeholder impact analysis of infrastructure project management in developing countries: a study of perception of project managers in state-owned engineering firms in Vietnam. Construction Management and Economics, 27:11, pp 1129-1140.

[33] Mnaranara, T.L. (2010). The importance of community participation in ongoing construction of primary schools. Morogoro, Tanzania - a case of Mlali and Mzumbe wards. An MSC thesis. The University of Agder.

[34] Dalby, S. and Mackenzie, F. (1997). Reconceptualising local community environment: Identity and threat. Area, 29:2, pp $99-108$.

[35] Fortmann, L. and Roe, E. (1993). Talking claims: Discursive strategies in contesting property. World Development, 23:6, pp 1053-1063.

[36] Clark, A. (2007). Understanding Community: A review of networks, ties and contacts. Economic and Social Research Council (ESRC) - National Centre for Research Methods (NCRM) Working Paper Series, 9:07. Available online: http://eprints.ncrm.ac.uk/469/http://eprints.ncrm.ac.uk/469/1/ 0907 understanding_community.pdf

[37] Zenter, H. (1964). The State and the Community. Sociology and Social Research, 48, pp $414-427$.
[38] The Union of South Africa, (1950). Group Areas Act No 41. Cape Town.

[39] Maddaloni, F. (2015). Stakeholder Management: Rethinking the Role of Local Communities in Megaprojects. A Review and Synthesis of the Literature, Conference Proceedings of Future of Places Conference, Stockholm, 29 June 2015.

[40] Alli, N. and Emery, S. (1994). Community participation in development projects with emphasis on the road industry. Sixth Conference on Asphalt Pavements for Southern Africa. 1994. ISBN 1874968047.

[41] Khan, Z. (2005). Evaluating the importance of community participation in infrastructure delivery in the Western Cape. An MSc thesis. Cape Peninsula University of technology.

[42] Chambers, R. (1995). Paradigm shift and the practice of participatory research and development, Power and Participatory Development, Theory and Practice, Nelson and Wright (Ed), Intermediate Technology Publications, London.

[43] Thwala, W.D. (2009). Experiences and challenges of community participation in urban renewal projects: The case of Johannesburg, South Africa. Journal of construction in developing countries, 14: 2, pp 37-54.

[44] Rosario, V. D. and Goh, K. H. (2007). Community Stakeholder Management in Wind Energy Development Projects: a planning approach. An MSc thesis. UMEA University Sweden.

[45] Kambuga, Y. (2013). The role of community participation in the ongoing construction of ward based secondary schools: lessons of Tanzania. International Journal of Education and Research, 1:7, pp 1-10.

[46] Finsterbusch, K. and Van Wicklin III and Warren A. (1987). 'The Contribution of Beneficiary Participation to Development Project Effectiveness', Public Administration and Development, 7:1, pp 1-23.

[47] Nalewaik, A. and Anthony, M. (2015). Project stakeholder concerns and expectations, in PAQS 2015: Proceedings of the 19th Pacific Association of Quantity Surveyors Congress. Yokohama: Japan, pp 1-10. 25 May - 1 June 2015. 